\title{
Implementation of Scientific Approach with Video Media in Learning Social Sciences in Elementary Schools
}

\author{
Tri Murwaningsih ${ }^{1}$, Muna Fauziah ${ }^{2}$ \\ \{murwaningsih_tri@staff.uns.ac.id ${ }^{1}$, munafauziah6@gmail.com² ${ }^{2}$ \\ Universitas Sebelas Maret, Surakarta, Indonesia ${ }^{1}$, Institut Agama Islam Nahdlatul Ulama Kebumen, \\ Kebumen, Indonesia ${ }^{2}$
}

\begin{abstract}
This study aims to develop a lesson plan on the material of economic activities through a scientific approach with video media and explain the influence of the scientific approach on student learning outcomes. The research method used a pre-experimental design with a one-shot case study design. This study's target was 21 fourth-grade students in Public Elementary School 2 of Tanggeran, Kebumen. For sampling, the purposive technique was employed. The data collection was then conducted through observation, documentation, and written tests. Besides, the data analysis technique utilized descriptive and inferential statistical analysis. This research produced lesson plans based on scientific approaches and video media. Also, it revealed a positive influence on cognitive, affective, and psychomotor learning outcomes, with the completeness achievement of more than $85 \%$ of all students. Further, this finding can become a recommendation for teachers to apply a scientific approach with video media in elementary schools.
\end{abstract}

Keywords: scientific approach, video media, lesson plans, elementary school

\section{Introduction}

Social science is a simplification or adaptation of social science disciplines and basic human activities, which are organized scientifically for educational purposes [1]. At the elementary school level, social science learning is related to social science disciplines integrated with other knowledge and packaged scientifically for learning purposes [2]. Based on the Competency Standards and Basic Competencies for elementary schools in the Regulation of the Minister of National Education Number 22 of 2006 concerning content standards for elementary and secondary education units, social science is defined as a subject that examines a set of events, facts, concepts, and generalizations related to social issues. The content of social science lessons is designed to develop knowledge, understanding, and analytical skills on the community's social conditions to enter social life [3].

The hope of learning social science is that children become responsible, democratic, and peace-loving citizens [4]. With the existence of social science education, children are expected to have a strong soul and spirit of supporting and carrying out national development . It aligns with the social science learning objectives, namely, to develop basic knowledge and skills useful for students in everyday life and as a provision to continue education to a higher level 
[5]. Thus, the goals of social studies education need to be realized by educators to the maximum so that social studies learning is carried out optimally and in line with expectations.

Considering the purpose and essence of social science education, the implementation of social science education should prepare, guide, and shape students to master the basic knowledge, attitudes, values, and skills to live in society. Therefore, teachers are needed to support the success of educational goals. In this case, teachers must have supporting competencies. These competencies include pedagogic, personality, social, and professional competencies [6]. The task of teachers is not only to transmit the knowledge they have to students [7] but also able to shape the personality of students [8], able to assess the level of students' abilities [9], and able to master the class well [10]. In addition to teachers, the use of a learning approach is also required to help teachers realize maximum social science learning. For this reason, teachers must be able to create interesting learning conditions and learning processes through the use of approaches to media promotion among students [11].

Based on observations on social science subjects at an elementary school in Kebumen Regency, it was revealed that there were gaps in the learning process. The gap, among others, is that the processional ability displayed by the teacher was still standard, and the teacher paid less attention to the students' needs in learning. It could be seen in the lesson plans prepared by teachers, which have not been categorized as good. This category was seen from the formulation of competency achievement objectives, method selection, teaching and learning activities, media selection, and selection of learning resources. The observation results also showed that teachers only used learning resources in the form of books in the classroom. Whereas in the environment around the school, there were many learning resources and could be used to support the learning process. By looking at these conditions, the teacher's efforts that were not optimal would lead to student learning outcomes. Based on the interview results with classroom teachers, the mean value of social science learning was 67 . This value was still below the good category or the minimum completeness criteria of 75 . Therefore, alternative solutions to problems that occur in the school are needed.

In connection with the above problems, efforts to improve the quality of social science learning are urgent to be realized. One alternative thought to be a bridge to overcome this teacher anxiety is implementing a scientific approach in social science learning. Related to this, the scientific approach is a concept made so that students actively build concepts, laws, or principles, which are carried out in several stages: observing, formulating problems, formulating hypotheses, collecting data, analyzing data, drawing conclusions, and communicating [12]. This opinion is reinforced by previous researchers, who explained that the use of the scientific method is to explore science to children by providing a systematic way to attract or involve children in observing, asking, predicting, trying, summarizing, and conveying results [13]. Thus, the learning atmosphere is expected to be more conducive, fun and encourage students to discover various discoveries directly through observation.

In addition to employing a scientific approach, media in accordance with the students' characteristics are needed, one of which is collaborating the scientific approach with video media. Video is an effective tool to build the learning process. Video media is a non-printed teaching material that presents moving images accompanied by sound and can directly reach the students [14]. This media can convey audio-visual-motion messages, just like films and television. The messages conveyed can provide information, educate, and teach [15]. Therefore, social science learning by applying a scientific approach accompanied by video media on economic activity materials is expected to encourage students to be more confident, active, responsible, and develop collaboration skills. 
Based on the study of the problems described above, this research implemented a scientific approach with video as a process in a planned and directed manner. For this reason, this research was directed at developing a social science lesson plan with a scientific approach and video media and explaining the influence of a scientific approach on social science learning outcomes. The purpose of this study included developing a social science lesson plan through a scientific approach with video media and explaining the influence of the scientific approach on social science learning outcomes.

\section{Research Methods}

This pre-experimental design research used a one-shot case study design [16]. This research's population was fourth-grade students at Public Elementary School 2 of Tanggeran, Kebumen, who studied economic activities. The technique of determining the sample was by purposive sampling. Through this technique, 21 students were determined as the research sample. Data collection techniques then employed test, observation, and documentation techniques, while data analysis techniques utilized descriptive statistics and inferential statistics. Descriptive statistical analysis is a statistic used to analyze data by describing the data collected. This study used descriptive analysis by presenting a table of the findings obtained. Meanwhile, inferential statistical analysis was employed to draw conclusions and make decisions from the results carried out. As for the conclusion, it was information about the influence of the scientific approach with video media on student learning outcomes.

\section{Results and Discussion}

The lesson plan used applied a scientific approach. This approach is in accordance with a copy of the attachment to the Regulation of the Minister of National Education Number 65 of 2013. In the regulation, the learning steps refer to the scientific approach and character building, primarily in the core activities. The core learning activities in lesson plan 1 are presented in Table 1.

Table 1. Core learning activities in lesson plan 1

\begin{tabular}{ll}
\hline Learning steps & Learning activities \\
\hline Observing & Observing the teacher's explanation about economic \\
& activities in the surrounding environment \\
Asking & Asking questions about economic activity \\
Collecting data & Gathering information based on videos and books \\
Associating & Solving problems by discussing \\
Communicating & Presenting the discussion results \\
\hline
\end{tabular}

Table 1 shows the data of learning steps and activities by applying a scientific approach. Lesson plan 1 has not combined a scientific approach with video media. The steps included observing, asking, collecting data, associating, and communicating. Characters that emerged comprised curiosity, conscientiousness, openness, caring, respect for others, love to socialize, 
love to read, discipline, objectivity, and self-confidence. The core learning activities in lesson plan 2 are shown in Table 2.

Table 2. Core learning activities in lesson plan 2

\begin{tabular}{ll}
\hline Learning steps & Learning activities \\
\hline Observing & $\begin{array}{l}\text { Reviewing the discussion results on economic activities } \\
\text { that have been observed through video } \\
\text { Conducting questions and answers and identifying various } \\
\text { economic activities close to the student environment }\end{array}$ \\
Collecting data & $\begin{array}{l}\text { Designing simple interview activities, conducting } \\
\text { interviews, and recording the interview results with } \\
\text { economic actors }\end{array}$ \\
Associating & $\begin{array}{l}\text { Processing interview data, answering the subject matter of } \\
\text { student worksheets and making conclusions } \\
\text { Reporting and presenting interview results }\end{array}$ \\
\hline
\end{tabular}

Table 2 above represents that learning activities have collaborated with video media as a tool to generate student enthusiasm for learning. Each step was associated with a previously observed video (in the first step). The pre-test results of cognitive, affective, and psychomotor learning outcomes before applying the scientific approach were displayed in Table 3.

Table 3. Pre-test results on student learning outcomes

\begin{tabular}{llll}
\hline Learning outcomes & $\begin{array}{l}\text { The mean of } \\
\text { pre-test }\end{array}$ & $\begin{array}{l}\text { Number of students } \\
\text { who completed }\end{array}$ & Not completed \\
\hline Cognitive & 78.14 & $47.62 \%$ & $52.38 \%$ \\
Affective & 81.50 & $76.19 \%$ & $23.81 \%$ \\
Psychomotor & 79.50 & $57.14 \%$ & $42.86 \%$ \\
\hline
\end{tabular}

Table 3 reveals that not all aspects of cognitive, affective, and psychomotor learning outcomes reached the specified classical completeness, which was $80 \%$. These results were pure results before applying the scientific approach in learning. After the scientific approach was implemented, the post-test results were much better than before. The post-test results on the scientific approach and character-building concerning the cognitive, affective, and psychomotor learning outcomes are exhibited in Table 4.

Table 4. Post-test results on student learning outcomes

\begin{tabular}{llll}
\hline Learning outcomes & $\begin{array}{l}\text { The mean of } \\
\text { pre-test }\end{array}$ & $\begin{array}{l}\text { Number of students } \\
\text { who completed }\end{array}$ & Not completed \\
\hline Cognitive & 85.71 & $85.71 \%$ & $14.29 \%$ \\
Affective & 87.45 & $95.24 \%$ & $4.76 \%$ \\
Psychomotor & 83.57 & $90.48 \%$ & $9.48 \%$ \\
\hline
\end{tabular}

From the results in Table 4, it is known that the mean post-test had reached the specified completeness $>80 \%$. The percentage of students who completed was also better than the pre- 
test results. The highest mean value was obtained in the affective aspect, with a mean score of 87.45, while the lowest was in the psychomotor aspect at 83.57. In general, all aspects had met the requirements. Thus, it could be concluded that the scientific approach has succeeded in improving students' cognitive, affective, and psychomotor learning outcomes.

Furthermore, the material for economic activities is a science related to social learning in society. This material is not just the mastery of a collection of knowledge in the form of principles, facts, or concepts but is a social science considered a process of acculturating culture with knowledge. In general, social science is taught in schools so that students understand the social science concepts and apply them themselves in solving social problems fully. Besides, nowadays, teachers need to train students to appreciate every kind of activity or one's work. Realizing how crucial this subject is, teachers are expected to choose the proper method or approach to optimize student involvement in the classroom so that the learning is more meaningful for students.

One way to create meaningful learning is to apply a scientific approach. According to Tang et al., the scientific approach directs students to infer problems in the form of problem formulations and hypotheses and teaches good values/characters directly [17]. In its application, students get the opportunity to investigate, search, develop, and report the work [17]. With this investigation, students will be able to think analytically, be honest, disciplined, think creatively and independently. The activity of presenting the work will bring up creative behavior, respect others' achievements, be responsible for their work results, work together, and communicate well. In the end, students will learn to analyze and evaluate the problemsolving process by way of thinking analytically and evaluatively because they have to reflect on their work results with the process they have gone through.

Based on the description of the results, it appears how vital the scientific approach is to be applied in the classroom. It aligns with previous research that the application of a scientific approach can develop various skills, such as critical thinking, communication, cooperation, investigation, and character-building [18]. The learning experiences students pass are useful for their daily lives. Besides, the scientific approach can also raise the natural character of students.

The scientific approach with video media and character building in the material for economic activities is presented as follows:

Observing. The step of observing prioritizes the meaning of the learning process. This finding is supported by previous researchers that the observation step provides benefits to students to observe objects directly or through the media [19]. In this step, the researcher combined video media as a tool. This media has the advantage of presenting moving images with sound. The existence of video media could attract students' attention because it was displayed on LCD and projectors so that they felt like watching television with a widescreen. This observing process could then fulfill students' curiosity [20]. That way, displaying on the LCD screen in the class could attract students' interest to observe and listen carefully. In addition, this study's results are relevant to previous findings, which proved that the use of video media could improve the behavior of stroke patients [21]. The patient was pleased with the impressions presented via video.

During learning, the teacher facilitated students to observe and trained students to listen and pay attention calmly to the essential things of an object. This observation activity included material on economic activities in the school environment, rural communities, and urban communities. The characters shown by students encompassed curiosity, conscientiousness, and earnestness. 
Asking. The teacher provided opportunities for students to ask widely. The material asked was related to things that had been observed, listened to, and read by students through video media. The teacher guided the students to ask questions. It was done so that students were not embarrassed. Through questioning activities, students could develop their curiosity and become more trained to ask questions. This finding is in line with the concept expressed by Ryan and O'Callaghan that the questioning step provides a way for learners to determine hypotheses so that the results asked will not be biased in the end [22]. This question became the basis for seeking further information and various sources determined by the teacher. The characters that emerged were developing creativity, the ability to formulate questions, and lifelong learning.

Collecting data. This activity was carried out to seek information from various sources in several ways. Students could read books, pay attention to phenomena, or conduct experiments. In this learning, the teacher utilized the resources of textbooks, people, and the surrounding environment. The experiences carried out by students in this study are consistent with Hadromi et al. that the step of collecting information is done by determining information from previous questions from various sources, both online and offline [23]. The characters developed included honest, politeness, respect, communication skills, and developing study habits.

Associating/reasoning. It is an information processing activity from the previous stage, either limited to experimental activities or initial observations. Information processing increases the breadth and depth of the material to the processing of information, looking for solutions from various sources. This activity was carried out to find the relationship between some information and the patterned relationship of learning materials with things relevant to real life. The contribution made in this finding is reinforced by previous findings, where the scientific approach allows the involvement of teachers and students and contributes to strengthening students' work skills [24]. This activity continued to conclude learning with a scientific approach. The characters developed consisted of honest, disciplined, obedient, hard work, and thinking inductively and deductively.

Communicating. In the scientific approach with video media, teachers are expected to open opportunities for students to communicate what they have learned. The activities carried out are like writing down or telling what they have found. Delivery was done in class and assessed by the teacher as a result of student or group learning. This stage opens opportunities for students to criticize the presentation results from other students.

In learning the material on economic activities, three learning outcomes were obtained. (1) Attitude; in accordance with the attitude characteristics, then one of the alternatives chosen was the affective process of receiving, carrying out, appreciating, living, and practicing. All activities were focused on character building to encourage students to carry out these activities. (2) Knowledge; the process of acquiring knowledge was carried out by knowing, understanding, applying, analyzing, and creating. The learning characteristics in the realm of knowledge have differences and similarities with the realm of skills. The learning approach was used to encourage students to produce creative and contextual work. (3) Skills were acquired through observing, asking, trying, reasoning, communicating, and conducting experiments. All economic activity materials supported students to carry out a series of these activities.

However, the implementation of a scientific approach with video media needs to follow educational principles. This principle will lead to the achievement of the social science education goals. If all steps in the scientific approach are carried out correctly, student learning outcomes are ensured to be better than before [25]. This statement is evidenced by research 
results that student learning outcomes, especially in social science content, have succeeded in increasing students' literacy skills and maximizing the learning process.

The scientific approach is also sufficient to prioritize the way of acquiring knowledge through inquiry. This inquiry strategy is designed to develop students' fluency and accuracy in problem-solving, concept-building, and hypothesis testing. The advantage of the inquiry learning process is that it encourages the growth of cooperative relationships, provides feedback, confirms the time in completing tasks, and develops the ability to formulate problems, analyze data, and conclude [26].

Based on Table 3, it is known that learning to apply a scientific approach could improve student learning outcomes in three domains compared to previous learning. However, this result does not mean that the previous model is ineffective compared to the scientific approach. However, through this approach, students felt more challenged and could grow their bright ideas during problem-solving. The combination of lessons presented in a scientific approach makes teachers and students more creative by providing unusual concepts or ideas. These three aspects are the focus of character education development. Character building through social science is related to the learning design that the teacher creates. Without planning, social science learning will be difficult and unable to grow children's character. The development of a social science learning approach also aims to provide students with a broader and better insight, emphasizing problem syntax, solutions, and consideration of limitations. This goal is in harmony with the previous research results that the development of social science learning models has proven effective in increasing students' knowledge and social attitudes [27].

Further, applying a scientific approach to social science learning as a process of inquiry and character building are two sides of one coin or two mutually reinforcing focuses. In line with Suyanto's findings, the scientific approach carried out according to the correct stages has proven to successfully bring up students' attitudes and characters, such as curiosity, criticalness, innovation, and cooperation [28]. The teacher's performance can also be maximized at every stage because the series of the scientific approach stages are easy to apply. On the other hand, the difficulties experienced can decrease with the learning time. Thus, character education will produce positive attitudes for students in the school environment if carried out consistently [29]. In order for a scientific approach in social science learning to be connected with character education, the involvement of staff, students, teachers, stakeholders, parents, and the community in the school environment is needed.

In addition, there are many reasons why character education needs to be internalized in schools. These reasons include (1) much violence between young people due to weak morals and awareness; (2) inculcating moral values in the younger generation is the primary function of civilization; (3) the role of the school as a mean for character education is needed when many students do not get the attention of their parents; (4) there are still universally accepted moral values; (5) democracy is needed for moral education; (6) effective character education can make schools more civilized, caring, and have good performance [30].

For this reason, the role of educators is crucial. Things that need to be done include (1) teachers must be involved in the learning process [31], (2) teachers interact with students [32], (3) teachers are role models for students in attitude [33], (4) teachers can encourage students to be active in learning [34], (5) Teachers can encourage and create change, (6) Teachers can help students develop social sensitivity and reduce emotions so that they appreciate and develop useful soft skills [35], and (7) the teacher must show love to the students. Character education integrated into science learning can provide meaningful experiences for students because they can understand, internalize, and actualize it through the learning process. This 
finding is consistent with previous findings that character education has developed into a part of the curriculum so that learning in schools makes children more comfortable [36]. As a result, these values can be absorbed naturally through daily activities. If the value of character education is developed through school culture, it is possible to develop positive values and attitudes toward developing student character [37]. Hence, character education must be a pioneer and priority because it is proven to bring benefits to children. If character education is not a school program, it is predicted that students will find it difficult to blend in with their environment. It is as researched by Moreno that students with low emotional intelligence have more difficulty responding to problems found in real life [38]. Students also do not care about each other. An example of reality found that students do not want to listen to others' opinions or suggestions, resulting in difficulties in communicating with others [39]. Character education in schools then becomes a vital need so that the next generation of the nation will be equipped with basic abilities that not only make them life-long learners but also function as positive individuals in their environment [40]. Thus, it is necessary to make instrumental efforts to make learning effective along with positive culture development. In this case, schools are the basis for character development at the formal education level, so that an effective approach or model of character education is needed.

\section{Conclusion}

This research has developed a lesson plan on the material of economic activities applying a scientific approach with video media and character building. This approach application has been proven to positively affect cognitive, affective, and psychomotor learning outcomes and has achieved the specified classical completeness, which was more than $85 \%$ of all students who took part in the learning. The description of the research results that have been discussed can be theoretically implied that the scientific approach application accompanied by media is an alternative approach and suitable to be applied to social science learning. Meanwhile, this research's practical implications are that social science learning through the scientific approach application with video media at each step can stimulate students' interest and enthusiasm in learning, practice speaking skills, the ability to formulate questions, provide space for opinions, improve students' cooperative attitudes, and practice language skills and systematic thinking. In addition, the success of learning through the scientific approach application with video media can be recommended to other teachers through teacher working group activities, teacher training, education, and other teacher professional development activities.

Acknowledgments. The authors would like to thank the principal, teachers, and students of the State Elementary School 2 Tanggeran who have been willing to become partners in this research.

\section{References}

[1] A. Ajidayanti and E. W. Abbas, "Utilization of tourism Bekantan Mascot as a learning resource on social studies," Innov. Soc. Stud. J., vol. 1, no. 1, p. 78, 2019.

[2] S. Ucus, "Exploring creativity in social studies education for elementary grades: Teachers' opinions and interpretations," J. Educ. Learn., vol. 7, no. 2, p. 111, 2017. 
[3] Minister of National Education, Minister of National Education Number 22 of 2006 concerning content standards for elementary and secondary education units. Indonesia, 2006.

[4] M. J. Kostelnik, A. K. Soderman, and A. P. Whiren, "Developmentally appropriate curriculum," in 5th edition)., USA: Pearson Education, Inc, 2011.

[5] D. Rizki Pebriana, "Effect of problem based learning to critical thingking skills," J. Elem. Educ., vol. 1, no. 1, pp. 109-118, 2017.

[6] B. M. Triyono, N. Mohib, G. K. Kassymova, G. N. I. P. Pratama, D. Adinda, and M. R. Arpentieva, "The profile improvement of vocational school teachers' competencies," Vyss. Obraz. v Ross., vol. 29, no. 2, pp. 151-158, 2020.

[7] I. Rissanen, E. Kuusisto, M. Tuominen, and K. Tirri, "In search of a growth mindset pedagogy: A case study of one teacher's classroom practices in a Finnish elementary school," Teach. Teach. Educ., vol. 77, pp. 204-213, 2019.

[8] I. Rissanen, E. Kuusisto, E. Hanhimäki, and K. Tirri, "Teachers' implicit meaning systems and their implications for pedagogical thinking and practice: A case study from Finland," Scand. J. Educ. Res., vol. 62, no. 4, pp. 487-500, 2018.

[9] N. Zeuch, N. Förster, and E. Souvignier, "Assessing teachers' competencies to read and interpret graphs from learning progress assessment: Results from tests and interviews," Learn. Disabil. Res. Pract., vol. 32, no. 1, pp. 61-70, 2017.

[10] J. A. Schmidt, L. Shumow, and H. Kackar-Cam, "Exploring teacher effects for mindset intervention outcomes in seventh-grade science classes," Middle Grades Res. J., vol. 10, no. 2, pp. 17-31, 2015.

[11] M. Simons, W. Meeus, and J. T. Sas, "Development of a questionnaire for teachers' competencies," J. Media Lit. Educ., vol. 9, no. 1, pp. 99-115, 2017.

[12] H. Tambunan, "The effectiveness of the problem solving strategy and the scientific approach to students' Mathematical capabilities in high order thinking skills," Int. Electron. J. Math. Educ., vol. 14, no. 2, pp. 293-302, 2019.

[13] H. K. Gerde, R. E. Schachter, and B. A. Wasik, "Using the scientific method to guide learning: An integrated approach to early childhood curriculum," Early Child. Educ. J., vol. 41, no. 5, pp. 315-323, 2013.

[14] D. A. M. M. O. Priantini, "The development of teaching video media based on Tri Kaya Parisudha in educational psychology courses," J. Educ. Technol., vol. 1, no. 4, pp. 448-455, 2020.

[15] N. D. Rahayu, Zulherman, and I. Yatri, "Animated video media based on Adobe after Effects (AEF) application: An empirical study for elementary school students," J. Phys. Conf. Ser., vol. 1783, no. 1, pp. 1-9, 2021.

[16] J. W. Creswell, Research design: Qualitative, quantitative, and mixed method approaches. London: Sage Publication, 2009.

[17] X. Tang, J. E. Coffey, A. Elby, and D. M. Levin, "The scientific method and scientific inquiry: Tensions in teaching and learning," Sci. Educ., vol. 94, no. 1, pp. 29-47, 2010.

[18] I. Siti Nugraha and D. Suherdi, "Scientific approach: An English Learning-Teaching (ELT) approach in the 2013 curriculum," J. English Educ., vol. 5, no. 2, pp. 112-119, 2017.

[19] A. In'am and S. Hajar, "Learning geometry through discovery learning using a scientific approach," Int. J. Instr., vol. 10, no. 1, pp. 55-70, 2017.

[20] L. H. Anas, J. Rajagukguk, and W. Bunawan, "Video technology media based on heat and temperature to improve of learner critical thingking," J. Phys. Conf. Ser., vol. 1485, no. 1, pp. $1-8,2020$.

[21] I. Muslihati, Y. G. Lisandy, R. Kasanah, and H. A. Winarko, "Effect of education media video on improve stroke prevention behavior in continued age in Wiyurejo Pujon Malang," J. Nurs. Pract., vol. 1, no. 2, pp. 12-17, 2018.

[22] M. Ryan and A. O'Callaghan, The scientific method. Cooperative Ext. Nevada: Reno, 2002.

[23] H. Hadromi, S. Sudarman, H. Yudiono, F. A. Budiman, M. N. Majid, and K. N. C. Permana, "The learning strategy based on scientific approach to strengthen the employability skill of teacher candidates," Int. J. Instr., vol. 14, no. 2, pp. 551-570, 2021. 
[24] N. S. Stephenson and N. P. Sadler-McKnight, "Developing critical thinking skills using the science writing heuristic in the chemistry laboratory," Chem. Educ. Res. Pract., vol. 17, no. 1, pp. 72-79, 2016.

[25] Asrizal, A. Amran, A. Ananda, F. Festiyed, and R. Sumarmin, "The development of integrated science instructional materials to improve students' digital literacy in scientific approach," $J$. Pendidik. IPA Indones., vol. 7, no. 4, pp. 442-450, 2018.

[26] B. K. Khalaf and Z. B. M. Zin, "Traditional and inquiry-based learning pedagogy: A systematic critical review," Int. J. Instr., vol. 11, no. 4, pp. 545-564, 2018.

[27] S. Uge, A. Neolaka, and M. Yasin, "Development of social studies learning model based on local wisdom in improving students' knowledge and social attitude," Int. J. Instr., vol. 12, no. 3, pp. 375-388, 2019.

[28] S. Suyanto, "The implementation of the scientific approach through $5 \mathrm{~ms}$ of the revised curriculum 2013 in indonesia," Cakrawala Pendidik., vol. XXXVII, no. 1, pp. 22-29, 2016.

[29] N. B. Ugurlu, "Important values of American and Turkish students nihal," Eurasian J. Educ. Res., vol. 55, no. 4, pp. 91-108, 2014.

[30] F. Junaidi, I. Cahyani, and Yulianeta, "The internalization of character education values for students in Islamic Boarding School," Int. J. Sci. Res., vol. 7, no. 2, pp. 1581-1585, 2018

[31] J. P. Bishop, L. L. Lisa, A. P. Randolph, W. Lan, P. S. Bonnie, and L. L. Melinda, "Obstacles and affordances for integer reasoning: An analysis of children's thinking and the history of mathematics," J. Res. Math. Educ., vol. 45, no. 1, pp. 19-61, 2014.

[32] J. Caicedo, "Teacher activities and adolescent students' participation in a Colombian EFL classroom," PROFILE, vol. 17, no. 2, pp. 149-163, 2015.

[33] C. Laborde and M. J. Perrin-Glorian, "Introduction teaching situations as object of research: Empirical studies within theoretical perspectives," Educ. Stud. Math., vol. 59, no. 1-3, pp. 1-12, 2005.

[34] J. Harmer, The practice of English language teaching (4th ed.). Edinburg, UK: Pearson Education, Inc, 2007.

[35] N. F. Fuadiah, D. Suryadi, and T. Turmudi, "Analysis of didactical contracts on teaching mathematics: A design experiment on a lesson of negative integers operations," J. Math. Educ., vol. 6 , no. 2 , p. $157,2017$.

[36] T. Muhtar and R. Dallyono, "Character education from the perspectives of elementary school physical education teachers," Cakrawala Pendidik., vol. 39, no. 2, pp. 395-408, 2020.

[37] H. Heriansyah, "The importance of character education: The english teacher's efforts and challenges in students' character building," in Proceedings of the international conference on the roles of parents in shaping children's characters (ICECED), 2018, pp. 429-434.

[38] L. A. S. R. Moreno, "Emotional intelligence and academic ahievement," Liceo J. High. Educ. Res., vol. 13, no. 2, pp. 49-65, 2017.

[39] A. S. A. Lawrence and T. Deepa, "Emotional intelligence and academic achievement of high schoolstudents in Kanyakumari District," Int. J. Phys. Soc. Sci., vol. 3, no. 2, pp. 101-107, 2013.

[40] L. P. Artini and N. N. Padmadewi, "Character education practice in primary school in Bali," in 1st International Conference of Innovation in Education, 2019, vol. 178, pp. 535-540. 